\title{
Micro-Politics of Substitutive and Synergetic Partnerships
}

In 2007, a group of residents in Telepi, Zacatecas, mobilized swift opposition to the new mayor when he began paving over the cobblestone streets near the central plaza. "The pavement projects were ruining the provincial feel of our town, so we made him [the mayor] stop," said Umberto, a local resident. Citizens circulated a petition throughout Telepi and collected the signatures of all those against the pavement project. A resident wrote a position piece in the local newspaper that called on the mayor to cease the project. And active members of the church group, Rotary club, and parent-teacher association organized a town hall meeting to voice opposition to the mayor's administration. The political opposition was successful and the mayor ended the pavement project. Telepitense residents used the social connections and skills they had developed during coproduction activities with previous municipal administrations to hold the mayor to account for his unpopular actions while in office. Residents mobilized collective action as a mechanism of social control and, for all those who opposed the pavement project, it made them feel politically empowered.

Citizens had serious objections to the pavement project because they enjoyed the quaintness of the main courtyard and cobblestone streets where, on weekends, sellers hawked their wares from market stalls and families strolled with their children, popsicles (paletas) in hand, while musicians played and friends chatted. Residents did not want their plaza any more "modernized" than it already was. Intense out-migration to the United States had brought back customs and American culture that many nonmigrant residents disliked. Since citizens had previously engaged in selecting, funding, and coordinating public goods projects with previous municipal administrations through a transnational partnership with a 
popular migrant club, the new mayor's dismissal of the active involvement of civil society in decision-making of public works was disconcerting to residents. Because residents had become accustomed to discussing and influencing public projects, the mayor's top-down directives were an insult to the participatory spirit in which more than 30 projects were implemented in Telepi over a six-year period. Citizens involved in coproducing public works with migrants and municipal officials came to value political deliberation, and when they felt like their participation was being threatened by a dismissive mayor, they did something about it.

What role did the transnational partnership play in residents' political engagement? How did Telepitenses develop the capacity and political will to mobilize for a cause they cared about? The political opposition organized by Telepitenses in response to the actions of an unpopular mayor and his preferred public works project offers a lens through which to analyze how synergetic transnational partnerships have unanticipated effects on citizens' political engagement in public affairs in and beyond the coproduction process. Citizens of Telepi were empowered to voice their concerns directly to the mayor and his administration because interactions with municipal officials had become routine and they learned that they could influence public decisions by speaking out.

I have two central objectives in this chapter. First, I describe the conditions under which two organizational forms of transnational partnership-synergetic and substitutive-emerge in hometown settings. I trace the transnational process of producing public goods over time to show how community inclusion and government engagement combine to produce synergetic and substitutive types. If one's research goal is the search for causal mechanisms, it is vital to study not a static network but one that changed, and then to identify dates of change. Because inclusion and engagement change over time with the expansion (and decay) of bonding and bridging social ties and the electoral incentives of political officials, so too does who is involved in the process of coproducing public goods wax and wane.

The second goal of the chapter is to identify how synergetic and substitutive partnerships affect citizens' participation in civil society and the local political process. In each case, I describe how the two types of transnational partnership, substitutive and synergetic, affect participatory engagement and government responsiveness. The two cases in this chapter represent distinct transnational partnerships in different municipal contexts but share similar organizational forms. By comparing similar partnership cases, I show how migrant social embeddedness and political institutions shape migrant-state collective action and the spillover effects of cross-border public goods provision across hometowns over time.

In the first case of El Cerrito, Guanajuato, I explain how the absence of migrant bridging ties and government engagement in the early stages of coproduction led to a more substitutive partnership. In the first two years of coproduction, the migrant group substituted for government provision of public services with the 
support of state and federal matching funds. But over time, migrants learned to construct social relationships with key community stakeholders through social events and recruitment activities. The construction of bridging ties and renegotiation of community membership through quotidian participation in social life of the hometown expanded who was involved in the coproduction of public works. In return, the increase in community inclusion triggered more government engagement, which changed the partnership to a more synergetic organizational form. As a result, an increase in local participation in civic and governmental affairs resulted and municipal responsiveness in El Cerrito improved.

By contrast, in the second case of Telepi, Zacatecas, members of the migrant club were more socially embedded in the hometown community from the start and the municipal administration was actively engaged in project deliberations and coordination. However, the synergetic partnership was disrupted when electoral transition introduced a mayoral administration that was uninterested in the participation of civil society in public affairs. Residents and migrants drew on the trust, reciprocity, and social network ties forged during the synergetic period to continue public works projects without municipal financing and technical support, which led to a period of substitution. Additionally, citizens censured the mayor's performance and forced him to change his behavior while he was still in office, introducing a measure of social accountability in local politics. Residents had learned how to use democratic mechanisms to voice their opposition to an unpopular mayor during the synergetic period that paid dividends at a later date.

While migration intensity, poverty levels, and club capacity are relatively constant across the cases in this chapter, sociodemographic and political characteristics of the hometowns vary. Where relevant, I identify how local historical conditions such as land tenure arrangements, political scandals, and social cleavages affect the formation and evolution of transnational partnerships through their effects on community inclusion and government engagement. I present a more detailed description of the case selection method for all the partnership cases in Data Appendix A.

\section{SYNERGETIC AND SUBSTITUTIVE TRANSNATIONAL COPRODUCTION IN EL CERRITO, GUANAJUATO}

Located 30 miles outside the Selvillo municipal county seat is El Cerrito, one of the more populated localities in the county and home to about 4,00o residents. Reymundo and Francisco, two migrants who left El Cerrito in their teens for the northern border, formed a migrant club in 2005. The acquisition of green cards and stable, well-paying jobs allowed the migrants to cross the border and visit their hometown more regularly. These visits, more frequent as the friends grew older, made them miss the traditional ways of life of the Guanajuato countryside, but also brought into sharper contrast the lack of public goods provision in their 
native El Cerrito. They knew El Cerrito lacked jobs, as the two migrants had emigrated with over a third of the adult male population amidst severe economic crisis in the early 1990s, but the experience of growing up in a major U.S. city with paved roads, sanitation, garbage collection, and good public schools revealed just how forgotten El Cerrito was to the municipal government. The tipping point came, though, when a schoolmate of Reymundo's was involved in a car accident and died on the side of the road due to a lack of emergency medical care. The migrants were motivated to act. When they heard about the 3x1 Program during a visit to the Mexican consulate, they decided to form a club after doing some research on the internet.

Club El Cerrito's goals were modest at the outset. The migrants hoped to complete a few projects through the 3x1 Program. But the club exceeded their expectations and coproduced more than 30 public goods projects such as paved roads, sidewalks, drainage, and a recreation area for a local school, among other projects. Additionally, the club grew from a few core members to a membership base that was about 1,00o paisanos strong, with migrant members spread out across the U.S. where Cerritenses resided. ${ }^{1}$ In seven years, the club committed more than $\$ 2$ million (USD) in collective remittances, one of the highest totals in the state of Guanajuato. ${ }^{2}$

Perhaps more striking to the migrants and Cerritense residents was how much more involved local residents became in public goods provision in their community as more projects were completed. Decades-old political scandals and corruption had depressed political participation in El Cerrito and community residents were divided along party lines, which negatively affected coproduction activities in the beginning. But as Reymundo, Francisco, and other migrants reintegrated into the social life of the hometown while living abroad, residents began to trust them more and felt comfortable taking part in coproduction activities with them and, later, the local government. The scaling up of community participation in public goods provision had positive spillover effects on local government engagement. As more residents became involved in project activities, municipal officials increased their involvement and recruited a resident from El Cerrito to join the administration to coordinate $3 \times 1$ projects across all of Selvillo's localities and the county seat. By 2011, residents directly engaged with municipal government officials without much involvement from the migrant club and created three new civic associations to solve local problems.

\section{SCARCITY OF BRIDGING TIES AND THE “MAÑANA MENTALIDAD” OF MUNICIPAL GOVERNMENT}

After migrating at the age of 14 with his mother Rosalia, Reymundo was miserable in the U.S.- - he did not speak the English language well, and he missed his home, friends, and the slower pace of life. Everything felt foreign and awkward 
to him. But after he learned English, finished high school, then college, and became a teacher in San Diego, he felt more attached to the U.S. and remained connected "there," to El Cerrito. "Because I left as a teenager," Reymundo said, "the umbilical cord was still attached. I am an American citizen now. But I've never stopped being from El Cerrito." During years of public schooling in the U.S., and through friendships with immigrants and native-born Americans alike in college classrooms and in the Latino fraternity that he founded, Reymundo slowly developed an American identity while he maintained deep attachments and a few friendships in his hometown. While five of his six siblings decided to stay permanently in California, Manuel, one of his brothers, was deported and returned to El Cerrito with his wife and five-year-old son. Tragedy struck in 2008 when Reymundo's father passed away. When her husband died Rosalia returned to help Manuel with the family pig farm (ganaderia) and opened a small store (abarrote) with remittances the family had saved up in the U.S. Even though Reymundo felt strongly connected to El Cerrito-he owned a home, visited regularly, had a few close friends from elementary school and family-his absence eroded more extensive social ties in the community beyond his close circle of friends and relatives.

When the club began working with the municipal government on the first two coproduction projects, public lighting and the extension of the electricity grid, popular residents of the hometown were suspicious of the club's intentions. The residents of El Cerrito did not hold high opinions of political officials in the municipal government or the local delegate who represented their interests in the municipal administration.

Until the late 1990s, the PRI dominated municipal elections, with many in the political opposition accusing the PRI of vote buying and outright corruption. The PAN's growing base of support across Selvillo, especially in El Cerrito, was increasingly vocal about the PRI's wrongdoings. Political differences were further entrenched by local political scandal. Between 1988 and 1994, the PRI delegate of El Cerrito allegedly stole money from the patron saint festival funds and used the town's resources for political activities. The delegate and his supporters vehemently denied these allegations, but residents took sides along party lines. Although 10 years had passed and the PAN had successfully won an election during that period, Cerritenses still had misgivings about anyone in the delegate position and about political officials more generally. As a result, few residents wished to hold the office for fear that residents would blame them for any issues that might arise in the course of their tenure. A history of distrust in the local government ${ }^{3}$ and the municipal delegate position had accumulated over the previous 15 years and created social cleavages along party lines in El Cerrito. When locals heard that some migrants from El Cerrito were working with the local government and the delegate on public lighting and electricity projects, they were skeptical about the migrants' intentions given residents' misgivings about public officials. 
In addition to general distrust of political officials, El Cerrito neighbors did not have high levels of what Putnam and others refer to as social capital, trust, and norms of reciprocity in the social base of the town. Contributing to social divisions in El Cerrito was the system of land use for agricultural production, one of the pillars of economic activity in Selvillo and the surrounding area. In El Cerrito, unlike many other localities in Guanajuato, land use was not based on ejido, one of the hallmark achievements of President Lázaro Cárdenas's agrarian reforms in which over 18 million hectares of land were redistributed to the peasantry for communal use. ${ }^{4}$ Rather, in 1992 with the introduction of neoliberal economic reforms, large parcels of land were sold to private companies and agricultural production was increasingly industrialized in this part of Guanajuato, which upset traditional modes of economic production and displaced Cerritenses from domestic cultivation and subsistence. The privatization of land became very expensive in El Cerrito and only a few families, including Reymundo's, owned private parcels. The change in land tenure in the early 1990s was a significant factor in the mass emigration from El Cerrito that accompanied macroeconomic crisis. Those who owned local land were viewed as elites, and El Cerrito was separated into the haves and have-nots.

Mass emigration further exacerbated social inequality in the locality because exit allowed many families to subsist on remittances from the U.S. Migrant families acquired new sources of revenue and were not dependent on employment in local agriculture. Throughout the 1990 s and early 20oos, migrant households fixed up their homes, sent more children to school, and purchased creature comforts that many in El Cerrito without migrants abroad could not afford. For those residents like Jessy, a construction worker who had previously emigrated to Texas and then returned to El Cerrito because of hardships in the U.S., migrants who had "made it" in the U.S. were often "showoffs" who made life for nonmigrant families even harder than it already was. The social and political context in El Cerrito made coproduction challenging for the migrant club. Allegations of political scandal, alleged political corruption and rent-seeking that accompanied high levels of unemployment, pockets of intense poverty, and perpetual migration, which introduced jealousy and competition between migrant and nonmigrant neighbors, had reconfigured citizen-state relations in El Cerrito. The combination of these local factors created severe challenges for the cross-border provision of public goods for migrant clubs like Reymundo and Francisco's.

In 2005, most local residents who were aware of the new HTA were suspicious of the migrants' motives. Members of Club El Cerrito had migrated many years ago and although they still had a few family members in town and friendships from elementary school, the migrants lacked bridging ties to key stakeholders in the community. Jessy was someone in El Cerrito who "knew everybody" according to many residents, but not Reymundo and Francisco. He had not heard about the 3x1 Program or about what the migrant club planned to do in the town. So when 
he saw the migrants talking to construction crew members in El Cerrito who were there to dig holes for new electricity lines, Jessy was suspicious and asked other residents about the paisanos and the projects. No one Jessy talked to knew about the club or the project, further raising his suspicions. "Before I knew Reymundo like I know him now, I thought there must be something going on because where did the paisanos get the money for the project? And how was it happening so fast? Nothing happens fast in El Cerrito and if it involves the municipality you have to wonder because they do nothing here," he said. The lack of recognition between community stakeholders such as Jessy and migrant HTA leaders actively working to improve public goods provision in the town reflected low levels of bridging social ties.

Furthermore, pervasive mistrust of local officials responsible for public goods provision made residents suspicious of the cooperation between the migrant club and local government, even though the municipal government was not actively involved in the $3 \times 1$ project at all. Local residents did not have accurate information about who was involved in the project. From their vantage point, the migrants' cooperation with local government made them guilty by association given the history of political opportunism and scandal in El Cerrito. And gossip about the club and the migrants while they were back in the U.S. created a circle of negativity around the club early on.

Additionally, Reymundo and Francisco's long absence from the hometown, despite annual visits, had eroded their social ties beyond their close circle of friends and family. While the migrants felt connected to El Cerrito and claimed to have good intentions, residents had no reason to trust them. As Juanita, a local shop owner, told me, "People in El Cerrito keep to who they know. It's changing more now, I guess. But when Jessy and Miguel (a local schoolteacher) told us about the migrants doing projects with the municipio, I first thought they were crazy. Maybe they just don't know about politicians here anymore because they live in California." The deficiency of migrants' social ties made popular residents like Jessy publicly question whether Reymundo and Francisco had the authority to be involved in public goods provision in El Cerrito. It led others, like Juanita, to question their decision-making authority given the general skepticism locals had of political authorities in Selvillo.

Reymundo and Francisco lamented not talking to Jessy and other residents about what the 3xi Program was and what they wanted to do in El Cerrito before they started the projects. Reymundo said:

People are so used to the government not delivering that we thought we had to do a quick and easy project. We extended the electrical grid to a street that had never had electricity. We did the whole project in 20 days without the municipio. And still people didn't trust us. They were so suspicious. They would say, "How come it happened so fast? They must be corrupt; they are lunatics." ... I even had to show Jessy 
the receipts and the check we wrote for $3 \mathrm{x} 1$ just to get them to believe that we weren't trying to steal the money that we had fundraised for the town in the U.S. ${ }^{5}$

The migrants learned from the first two projects that they had to communicate more effectively with locals and give residents a stake in the public projects if they wanted to succeed. "We don't want to be associated with being nontransparent. We learned that we had to inform the town what $3 \times 1$ is and who we are if we wanted to keep going with projects; otherwise it's just more gossip (chisme) and negativity (negatividad)," said Reymundo. Migrant club leaders recognized that in future projects they needed to give residents "a piece of projects that means something to them" and that the coordination of projects should be "more interactive." While Francisco and the other migrant leaders genuinely believed more active involvement of the community would help reduce suspicion and criticism of their club, they also thought that if more citizens became involved, it could stimulate more engagement from the local government. Although the migrants learned from conversations with residents about how much they disliked government officials, the migrants also did not think they could do the projects on their own without municipal matching funds.

In the first few projects, local government shirked their responsibilities and held up completion of the public lighting project, which the migrants worried would further cast doubt on their involvement in El Cerrito with residents. Reymundo said that the municipal officials "had a mañana mentalidad, everything was, 'We'll get it to you soon, tomorrow, tomorrow' but nothing ever came. And since we weren't in El Cerrito we had to just keep calling and bugging them and nothing ever happened." The migrants' absence from the hometown made monitoring government activity nearly impossible. And without local residents to follow up with contractors and officials about project activities, the migrants feared they would not finish any projects, or worse, the remittances they collected from paisanos in the U.S. would disappear from the local treasury, which would surely end the club's development activities in the hometown.

While the $3 \times 1$ Program is designed to have all contributors match collective remittances one-to-one, the first municipal government (PAN) that Club El Cerrito worked with failed to deliver its 25 percent share of project costs and materials they promised the migrants as part of the $3 \mathrm{x} 1$ project approval process. The mayor and his administration stalled technical plans, neither delivering materials nor committing their share of matching funds. Additionally, migrant club members believed the officials tried to inflate project costs. "When we approached the mayor about the public lighting project and matching some funds for $3 \mathrm{x}$, he (the mayor) kept saying, 'Well, how much money does your club have? Tell us how much you have and then we can put together a budget.' But we were not stupid, we were not going to do that," said Reymundo. This was frustrating to the migrants because they talked to other migrant club leaders in nearby municipalities (Yuriria 
and Acambaro) who told them about how many projects they completed with the municipal administration through the 3x1 Program. This perplexed them since they knew Selvillo was a richer municipality and had resources to contribute to public works projects. ${ }^{6}$

The 2005-7 PAN administration was focused, however, on projects primarily in the county seat. Although the former mayor said he wanted to support El Cerrito and 3X1, he added, "What am I going to do, give projects to the little old ladies who live there? It is not a big population and I can do more with public resources in the cabecera." With skepticism growing from prominent townspeople about the migrants' involvement in public works, a reticent local government "partner," and the need to be accountable to paisanos across the U.S. who had fundraised and donated resources for the projects, Club El Cerrito worked without a municipal partner and substituted for the local government for the public lighting project, electricity project, and a street pavement project. "The longer the projects took (electricity and pavement) and we waited for the municipality to do nothing, the more the residents and paisanos in the U.S. thought we had something to hide. It was getting to be too hard. We talked about it and we said our time and reputation is more important than the municipality's 25 percent share, so we did it without them, just with state and federal matching funds," said Reymundo.

Due to internal political considerations at the local level, the initial phase of the transnational partnership was one of substitutive coproduction. For the electricity, public lighting, and pavement projects, Club El Cerrito contributed 33 percent to project costs even though the Selvillo administration had pledged support as part of the 3x1 Program approval procedure. With complementary funding from the state and federal governments, the club hired their own architect, and got help with technical planning from state-level officials they came to know at the COVAM project validation meetings. Beyond their agreement to participate in the 3x1 Program, the Selvillo municipal government was uninvolved in the early years of the club's activities. But this did not stop municipal officials from trying to take credit for projects. Residents of El Cerrito said that while the migrants were in the U.S., the municipal government had a car with a loudspeaker circulate through the town, listing the public projects they had completed in El Cerrito. When I asked the former director of social development about the credit claiming for projects, he gave me a candid response. He said, "Look, we did participate in 3x1, we let them use the municipio's truck for the projects. And we approved the projects for $3 \mathrm{x}$. It is not good if the migrants are doing projects and showing us up." With municipal elections around the corner and fiercer competition between the PRI and PAN, the local government did not want residents to perceive a municipal lack of engagement in El Cerrito.

The year 2009 marked a significant shift in the way in which coproduction projects were organized in El Cerrito and Selvillo more generally. Over the course 
of a year, Club El Cerrito changed how projects were selected, funded, and implemented in the hometown, which scaled up community inclusion and government engagement. Club El Cerrito recruited residents including Jessy and Miguel into club activities, an effort to get the prominent locals on "their side." The development of bridging ties to these key social actors in the hometown led to broader civic engagement and inclusion of an expanding segment of Cerritense residents in coproduction activities with the migrant club. The increase in citizen inclusion, in turn, prompted more engagement from local government in the coproduction of public goods.

\section{CONSTRUCTING SOCIAL TIES THROUGH SOCIAL EVENTS AND CITIZEN RECRUITMENT}

Manuel, Reymundo's brother and friend of migrant club leader Francisco, recommended club leadership meet with Jessy, Miguel, Dionisio, and other local residents who were critical of the club's involvement in town affairs to discuss the 3x1 Program. Since Manuel had moved back to El Cerrito, he knew who had bad-mouthed the migrant club around town. When Reymundo and Francisco approached the men during a visit to the town they decided to cohost a town hallstyle meeting where the club members would come and speak directly to local residents about public goods projects. At the meeting, the migrants explained to the 70 residents in attendance what the $3 \times 1$ Program was, how it worked, and what the club hoped to accomplish moving forward.

During the meeting, Reymundo solicited volunteers to participate in the selection and implementation of projects. This effort built the club's credibility and expanded the density and heterogeneity of social ties throughout the town. About 20 residents volunteered to form a mirror association they called the Public Works Committee (PWC) to work alongside the club. Additionally, Jessy and two of his close friends, informally referred as the "Hawks" (halcones), appointed themselves the watchdogs of both the migrant club and political officials. This additional committee effort was meant to ensure local residents that political officials involved in any $3 \times 1$ projects would not attempt to pocket the town's resources, which was still a concern of many residents at the meeting.

The construction of new social ties to Jessy and Miguel, the veteran schoolteacher, facilitated a number of additional bridging ties to the principal of the elementary school, teachers at El Cerrito's schools, and members of the church group, all of whom the club was interested in working with on different projects. Since many in the parent-teacher association and church group knew "the Hawks," when they put in a good word for the migrants, other residents were willing to chat with club leaders about coproduction activities. The branching out of the migrant social base to community stakeholders increased the HTA's visibility, credibility, and overall reputation. As a result, residents became more involved in 
the everyday tasks required of coproducing public works including fundraising, selecting projects, and monitoring the implementation of projects.

In addition to constructing social ties between migrant club leaders and prominent members of El Cerrito, Reymundo and Francisco sponsored social events in the hometown that helped raise funds for development projects. They threw rodeos (jaripeos), hired popular local bands to play, and sold tickets at a low price so that most residents could afford to attend. In an effort to be as inclusive as possible, residents recommended that the club use chicken wire around the bleacher seating so that poor residents without tickets could still watch the events through the wire. These kinds of small details went a long way toward improving migrantresident social relations in El Cerrito, especially with poorer citizens like Gloria. I asked her if she had attended the 3X1 meetings and spoken up about what kinds of projects she wanted for the town. She replied that she and others did not think it was appropriate to say anything about what they wanted because they did not have money to contribute to projects and did not have remittances to use for their share. But she reflected, during our chat, that when the PWC members walked around town, knocked on doors, and asked people what kinds of projects they would like, she felt more comfortable. The PWC member told her that she would not have to worry about paying if her family did not have the money and they could contribute labor or help at the fundraiser instead. Gloria felt more comfortable at this point, she said, and told the PWC member she thought drainage was a big issue in her part of town. Since the PWC members had a better understanding of the cleavages around poverty and migration in El Cerrito than the migrants did, they were able to strategize new ways to get people who were more reticent to vocalize their concerns about town issues.

The migrant club members credit a particular rodeo with really changing the townspeople's awareness of the HTA and their reputation in the town. Reymundo described the change this way:

\footnotetext{
After working together on a few projects, we (hawks, migrant club, and PWC) all realized we had to make the projects even more inclusive. We threw a huge jaripeo where we got the most popular banda in all of Guanajuato to perform. We sold tickets in the U.S. and Mexico for $\$ 100$ each (MXN pesos) and after we covered the costs of everything we made enough money to finance a recreation area for the schoolchildren. This was something the principal really wanted, and being in education, this was a project really close to my heart. And it was my elementary school too, which was special to me ... The whole town came, like 3,0oo people! It really showed people that we could do things together. Things really changed after that.
}

Over time, more local residents became interested in contributing to fundraising efforts for town projects, especially if it was a project they proposed. But not all projects were equally popular. Reymundo and a principal of the elementary school discussed building a computer lab at the school. When the parents heard about 
the idea some of them balked at the need for computers. "What do kids need with computers?" a parent remarked. But after the computer lab was installed, more parents asked the migrant club if they could have a computer lab at the schools where their children attended (middle school and elementary). To purchase more computers, the parents made food and sold dinner plates for a small fee to contribute resources to the $3 \mathrm{X} 1$ costs. In one of the fundraising events, the townspeople raised a hefty sum when they raffled off a mule. Social events helped raise money for public works projects, and as more townspeople became aware of and involved in projects, they felt more comfortable taking the initiative on their own.

The process of working out project selection with migrants, the PWC, and other parents had an additional social effect. Fundraisers and meetings about the projects became sites of social exchange and camaraderie for the residents of El Cerrito, which helped smooth over some of the previous political divisions across town. People who had never spoken before now had a reason to chat. The social events held for public goods projects also aided migrant club leaders' reintegration into the social life of the hometown. As one of the elementary school teachers noted, "Now, it's like they had been here. And when Reymundo comes, everyone likes to go to his parties." Over time, the paisanos' involvement in public affairs in the hometown was normalized, and increased social interactions and activities in the town helped to reintegrate their cultural membership in the community despite their residence in the U.S.

In addition to fundraising events in El Cerrito, the migrant branches continued to fundraise across the U.S. Over time, Cerritense paisanos had developed sophisticated networks that they mobilized for their social events in each branch and their fundraisers became more successful. Most raffles generated between \$3,000 and $\$ 4,000$ (USD). The migrants also learned after talking with other clubs in the Guanajuato federation that they could purchase trucks with lines of credit opened in the U.S. and raffle them off before they needed to make the first payment. For example, in one fundraiser, Reymundo purchased a truck in Mexico on credit, drove it back to California, and sold raffle tickets to Cerritenses in the U.S. The raffle fundraised the entire cost of the truck plus additional funds for future public projects. By 2011, Club El Cerrito had a working annual budget of about $\$ 100,000$. Between 2008 and 2013, in addition to expanding social network ties throughout El Cerrito, paisanos learned how to improve participation at their fundraising events when they joined the Guanajuato state federation of migrant clubs. On both sides of the border, Club Cerrito expanded the depth and breadth of their social ties to include more participants in coproduction activities. They also held social events that helped fundraising efforts, which gave migrants and nonmigrants spaces to socialize and expand their solidaristic ties to other Cerritenses in Selvillo and the U.S.

The expansion of migrants' bridging ties to different social circles in El Cerrito through active recruitment and social events embedded migrants back into the 
social life of the hometown. As a result, the degree of community inclusion in coproduction activities escalated after the town hall meeting in 2009. In addition to owning homes while living abroad and supporting development projects, migrant club members were regular attendees and sponsors of parties, dinners, and meetings during their annual visits to El Cerrito. Even though the migrants were absent for much of the year, when they were in town they acted as if they still lived there and engaged in everyday activities. When they were back in the U.S., they still communicated with residents through social media, texts, phone calls, and video chats. And their social participation in the quotidian facets of Cerritense life-roasting pigs in the backyard, driving around town with friends and visiting neighbors, sitting in the plaza and catching up with old acquaintances, having beers at jaripeos, attending mass, visiting godparents, and gossiping-not only reduced any concerns among residents about the migrant club members' intentions in the town; this participation went a long way toward building solidarity between citizens with different economic and political backgrounds. The migrant club's sponsorship of social and cultural events brought social segments of the hometown together to socialize and chat and solve problems together in new ways.

When migrant club leaders were in El Cerrito, they altered their dress, speech, and mannerisms to reflect local customs. In my observations, these subtle changes did not seem contrived. Rather, migrant club members learned how to move in and out of rural, small-town life and engage in a form of code-switching, which helped them forge social relationships that escalated community inclusion in public goods provision. Even though migrants' experiences living abroad had changed them-they spoke English, had American citizen children, became more educated, and attained social mobility-because they maintained and constructed solidaristic social ties with different segments of local society (bridging ties), migrant club members were seen as leaders in the community, social actors with legitimate voice to negotiate and coordinate with public officials to provide public goods for their fellow Cerritenses through the transnational partnership.

\section{COMMUNITY INCLUSION AND THE ESCALATION OF MUNICIPAL GOVERNMENT ENGAGEMENT}

As migrants became more socially embedded in the hometown, expanding their bridging social ties and recruiting more active stakeholders into the coproduction process, municipal government engagement in the transnational provision of public goods also increased. Prior to more extensive citizen inclusion, local officials were virtually absent from the coproduction process, although they attempted to claim credit for the provision of public projects funded through the 3X1 Program. Witnessing how effectively the HTA worked with the town to produce projects, the new administration elected into office after the substitutive period became 
more engaged in coproduction activities. Local elections became more competitive in El Cerrito and the difference in vote shares between the PRI and the PAN narrowed in the 2007 municipal race. When I asked the new Panista mayor about the change in attitude between the previous and current administration, he said:

We aren't a rich municipio, but we aren't a poor one either. We have a public works budget that allows us to do maybe one project in each pueblo, but most of the projects are completed in the county seat because that's where most of the people live. But when you have a really active HTA like Reymundo's, it looks bad if the municipio is not involved. The $3 \times 1$ Program gives us the extra funds we need to do projects in towns like El Cerrito, where not a lot of residents live.

As local residents participated in the coproduction process, local government became more interested in providing public works through the 3x1 Program. The mayor said, somewhat in jest, his new PAN administration did not want to compete and be "showed up" by El Cerrito's migrant club and instead wanted to work with them to improve public works using the additional matching funds from the state and federal governments.

Club Cerrito's active effort to construct social ties and recruit participation had substantial effects on not only the quality and quantity of coproduction projects, but also the extent of local government engagement and citizen-government interactions. As local government became more involved in coproduction, public officials had more occasion to discuss problems in El Cerrito and learn what Cerritenses needed in their town. Both high community inclusion and government engagement changed the substitutive transnational partnership into a more synergetic partnership. Residents' willingness to work with public officials did not happen overnight. And their skepticism of political officials never fully disappeared. Rather, in the first year of the new PAN administration, Reymundo and Francisco worked primarily with municipal officials on projects and acted as representatives of El Cerrito in their discussions and deliberations that concerned project governance.

After a few street pavement projects were successfully completed with the municipality's active involvement, some residents were more willing to interact with public officials. When migrant club members were back in the U.S., the PWC and the Hawks increasingly went to city hall and worked on technical plans with municipal engineers, collected local donations, and fundraised across town for projects the citizens wanted. In this manner, civil society leaders of El Cerrito (Miguel, Pepe, and Jessy, for example) completed another public lighting project, recreation areas for other schools, and several pavement and sidewalk projects. When workers hired by the municipality failed to report to work on time or materials did not arrive, Cerritense citizens complained directly to their contacts in the government. El Cerrito's local leaders provided much needed oversight to coproduction implementation with migrants in the U.S. 
Additionally, improved community inclusiveness led to more pronounced spillovers in local political participation as well as citizen relations with the local government. Coproduction drew attention from local residents who felt increasingly comfortable contacting the HTA and PWC leaders directly to report social problems in the town. To meet citizens' requests, the PWC and the HTA asked residents to form "citizen block committees." Each organized group of neighbors fundraised and helped pay for road pavement of their respective street. Many households used family remittances from the U.S. for their contribution, while others volunteered labor or had other families cover their contribution. The PWC worked directly with political officials and block committees to fund road pavements projects throughout town. In three years, almost every road in El Cerrito was paved.

The popularity of the 3x1 Program in the community led to another political development: the El Cerrito mayor created a new municipal 3x1 Program position and hired Jessy onto his staff.7 Jessy built connections within the local government and effective working relationships with the director of public works, the director of social development, the mayor, the director of the Office for Migrant Affairs, and the state and federal officials who approved 3x1 project proposals. Since the creation of the $3 \times 1$ municipal liaison position, Jessy has become embedded in the local municipal government, charged solely with working with citizens to coordinate coproduction projects - a kind of organizational entwining par excellence. As a result, a local resident who was seen as a de facto leader of the town represented El Cerrito's interests directly to the elected municipal administration. This municipal embeddedness further escalated residential involvement in public decisions about projects that affected the quality of their lives.

Moreover, as members of the PWC felt more confident in their role as community leaders, they decided to tackle some local problems on their own, independent of the 3x1 Program. After the town hall in 2009, the Hawks and the PWC worked on a series of coproduction projects with the HTA. But as more streets were paved and 3X1 signs were posted around El Cerrito, more residents wanted to voice their concerns about issues in the town. Jessy and Octavio, speaking to me over lunch one day in El Cerrito, recalled how residents texted them and posted messages on Facebook asking the new associations to help with different problems in the town, especially an uptick in crime and petty theft in a particular neighborhood. Residents contacted migrants in the U.S., the Hawks, and the PWC to complain about the crime problem and ask if they could hire more police patrols or private security for the town. Since Reymundo and Jessy had learned from a 3x1 representative at one of the COVAM meetings that this kind of project could not be funded by $3 \mathrm{x} 1$, residents took it upon themselves to form an additional committee to address the rise in local break-ins.

Some members from the Hawks, Club El Cerrito, the PWC, and 35 other residents formed the Public Security Committee, a kind of neighborhood watch 
group. They conducted foot patrols, broadcasted their presence in the neighborhood, approached the suspected thieves and threatened them with further punishment if they continued their activities. Soon after, the break-ins ended. With newfound confidence that they could solve problems on their own, members of the security committee continued to meet regularly and discussed other issues. This was an especially important development because members of the security committee included political party operatives for both the PRI and PAN who were not well acquainted.

In one of the meetings, residents discussed concerns that the doctor of the local health clinic was no longer keeping regular hours and was charging for services that were supposed to be free. Residents alleged he had also inflated the cost of medicine. Problems with the local health clinic caused serious consternation in El Cerrito because if the clinic was not open, residents had to travel 30 miles to the county seat to see a doctor and ambulances could not be counted on to travel to El Cerrito. On a few occasions, residents who were hurt when the clinic was closed had to pay for expensive taxis to get to the municipal hospital or had to travel on horseback while injured since many Cerritenses do not have their own cars. Other residents were unable to get their medicine and pregnant women often went without prenatal care when the doctor tried to charge them for routine services that were previously free. The PWC leaders organized a meeting between the clinic doctor and members of the municipal administration to coordinate a regular, consistent schedule of hours for the local clinic and the cost of services. The PWCs efforts were successful, and residents began to feel more confident going to the PWC to help with problems that surfaced in town.

The security group also began to work with members of the 2011 PRI municipal administration to bring social programs and services to El Cerrito. In 2011, the members of the Public Security Committee and the PWC worked together with the municipal government to coordinate information sessions on proper hygiene, domestic violence prevention, and nutrition for Cerritenses. By 2013, the civic associations of El Cerrito had registered with the municipal government and they worked on projects through other state-level programs beyond the 3x1 Program with and without the migrant club.

\section{POLITICAL CONSEQUENCES OF SYNERGETIC COPRODUCTION IN EL CERRITO}

In the first few years of the transnational partnership between Club El Cerrito and the Selvillo municipality, neither local residents nor municipal government officials were active contributors to the coproduction of public goods and services. The migrants were only able to complete the public lighting, electricity expansion, and some road pavement projects because they had the resources to contribute the municipalities' share of total $3 \times 1$ project costs, had complementary resources from 
the state and federal governments, and decided to hire their own labor, contractor, and materials when the municipality stalled project support they had previously promised but never delivered. High levels of HTA capacity allowed Club El Cerrito to substitute for municipal government engagement in coproduction activities.

Knowing that they would be unlikely to sustain the high level of engagement to compensate for an absent municipal government and involved local citizenry, the migrant club met with longtime residents outside of their bonding network of old friends and family to actively recruit key community stakeholders like Jessy, Miguel, and Pepe (leader of the Public Security Committee) into the transnational partnership. Through the formation of bridging social ties, the HTA expanded the number of local inhabitants involved in coproduction and improved the visibility and reputation of the migrant leaders of the club. Through the sponsorship of social events, such as rodeos, dances, raffles, and dinners, migrants and citizens began to work together on public goods projects, re-embedding migrants back into the social fabric of El Cerrito after having been gone for more than 15 years. As migrant leadership reinvigorated their social ties in the hometown, they were increasingly seen as cultural members of the community, which allowed them to recruit and work as collaborative partners with local residents on an array of public works projects.

As community inclusion escalated, Club El Cerrito worked extensively with local residents to fundraise, select, and coordinate all facets of public goods projects through the 3x1 Program, but without the engagement of local government. This early phase of the transnational partnership is best described as substitutive. However, as residents were increasingly involved in development projects, and political competition became fiercer between the PRI and the PAN in Selvillo, the 2007-9 municipal administration became more willing to contribute resources, offer technical planning support, hire labor, and deliberate with migrants and residents over project selection. To do so, the mayor created a new salaried position in the municipal government administration that worked directly with Club El Cerrito to coproduce public goods and services in localities throughout Selvillo.

The creation of a new participatory sphere of decision-making between migrants, residents, and municipal officials improved civic and political engagement in El Cerrito and led to the strengthening of citizen-state relations and government responsiveness. Cerritenses became more willing to work with migrants and no longer believed they had corrupt intentions. Scaling up of citizen inclusion led to the formation of three new community groups: public works, citizen block, and public security committees. Even though El Cerrito was a poor locality in a middle-income municipality with low levels of trust between residents and migrants and government officials, the coproduction process improved statesociety relations and citizen political participation as a result of increased citizen inclusion that evolved over time. And, as more local residents were integrated into the coproduction process and told their representatives what they wanted and 
needed in their town, municipal political officials became increasingly engaged. The migrant HTA's links to the local government and residents of the town created an alternative mode of participation in which citizens had more routine interactions with elected officials and felt more empowered to participate in solving problems through deliberation and democratic decision-making. Citizens did not necessarily start trusting political officials, but they were willing to work with them to advance Cerritense interests through a process of social and political learning that evolved over the course of several years of coproduction activities.

Moreover, residents reported that after they became more involved in coproduction and saw that the local government shirked their participation in the early substitutive period of coproduction, they felt compelled to vote against the PAN, even though they had been longtime PAN supporters. The PAN's vote share declined 11 percent in the El Cerrito district in the election after substitutive coproduction. The PAN still won the mayoral election, but the mayor and his new administration knew they would need to change their strategy from the previous PAN administration or face more opposition in a locality previously counted on as a Panista stronghold.

Relatedly, local government responsiveness improved in the change from substitution to synergy in the transnational coproduction process. Municipal government increased the average total share of expenditures on public works by three percent as well as public works spending by $\$ 466$ pesos (per capita) between the 2007-9 and 2009-11 municipal administrations. Most of the increase was attributed to matching funds from the $3 \times 1$ Program's state and federal partners and distributed to localities in Selvillo that had active migrant clubs including El Cerrito. The integration of a broad swath of local citizens voters into the coproduction process altered the local government's political incentives to engage in transnational activities as more citizens voiced their opinions about public goods decisions and were eager to participate in politics. Local residents participated in public life in El Cerrito at first indirectly through leadership of the HTA, but as citizen inclusion increased, more residents directly engaged in regular meetings and negotiations with elected representatives over development projects. Even though the political party of the mayor changed from PRI to PAN and back to PRI again, the synergy created between Cerritenses citizens and the local government carried over to the new PRI administrative authorities who were eager to work with the residents of El Cerrito and gain their political support.

\section{SYNERGETIC COPRODUCTION, INTERRUPTED, IN TELEPI, ZACATECAS}

Telepi is a rural municipality with about 9,ooo residents located in the southwestern part of Zacatecas. The rural municipality is off of Route 23 and nestled between municipalities in Jalisco and Zacatecas as the geographic boundaries between the 
two states zig and zag in this area. Most residents live in the cabecera municipal, but about 500 residents are scattered across the municipality's 26 localities that locals affectionately refer to as ranchitos. Telepi has a long history of emigration to the U.S. Many residents are proud of the fact that relatives first went to the U.S. as braceros in the late 1940 s and 1950 . Since then, emigration intensified during Mexico's macroeconomic crisis in the 1980s and 1990s, similar to El Cerrito, and migration has been viewed as an unfortunate necessity. Declining domestic agricultural production due to an extended draught in the 1990 s and farmers' inability to compete with American corn production after the implementation of NAFTA pushed more people to leave in search of jobs or scrape by on milpa crops for subsistence and sale in local and regional markets. A milpa field typically includes a dozen complementary crops including the "three sisters" (maize, beans, and squash).

Many Telepitenses initially left for Guadalajara, but eventually went to the U.S. Since the late 1980s, Telepitenses also went straight to the U.S. to find agricultural work in California and Oklahoma and manufacturing and construction jobs in Dallas, Chicago, and Atlanta. While more than a quarter of the Telepi community emigrated to make ends meet, many residents, both migrants and nonmigrants, describe it as a necessary evil. According to one local business owner named Julia, migrants bring back American culture (for example, tattoos, bad manners, focus on income and consumerism, less religiosity), which has upset traditional culture and the local values associated with rural life.

Telepi is a poor municipality with a high migration rate according to official statistics and has one of the oldest hometown associations investing in public goods projects in the state of Zacatecas. ${ }^{8}$ Familias de Telepi started as an informal group of families that all lived in the greater Los Angeles area (San Pedro, Bell Gardens, and Norwalk). Martin, an immigrant from Telepi who lived in San Pedro, formed a social group of migrants from Telepi who also lived in the area. Martin's club, called Club Social de Telepi, was mostly an informal group of several families who came together for social solidarity. Together the families enjoyed picnics, played soccer, and supported new migrants from Telepi when then arrived in the Los Angeles area.

About eight months after Club Social formed, Sarita and Leo, a married couple from Telepi, joined the club when they heard about it through a mutual friend at their church in San Pedro, California. Both Sarita and Leo were born and raised in Telepi and emigrated together 30 years ago. While Leo was from a farming family on the outskirts of town, Sarita was from a more prominent family who lived for generations in the center of the municipality. Her father, Ricardo, was a telegrapher who brought Morse code to the area and was considered a leader in the town who raised money for the first public light post. Sarita was a lot like her father, popular in her church group, and she was friendly with many families around town. Sarita said it was hard to leave Telepi, but the drought hurt Leo's crops and 
they could not see a way forward staying on the land. Reluctantly, Leo and Sarita, high school sweethearts who loved Telepi, emigrated first to Texas, where Leo's friend helped him get a job, and then to San Pedro, where he started his own small business. During their years in the U.S., Sarita and Leo started a family and had three American citizen children, two of whom served in the U.S. Army. Although she said she enjoyed her immigrant community in San Pedro where many residents from Zacatecas also lived and she knew how fortunate they were to be able to give their children opportunities they never had in Telepi (mainly, attend college), she never fully incorporated into U.S. society and always felt more "at home" in Zacatecas. In Telepi, the pace of life was slower and more traditional, which suited Sarita more than American culture in southern California. When she and Leo joined the social club, her nostalgia for rural life bloomed. As the years progressed and their children grew up and moved out of the house, the couple realized they wanted to do more for their hometown.

Part of what made the couple's cross-border involvement in Telepi possible was their ability to regularize their immigration statuses after the passage of IRCA in 1986. Soon after acquiring their green cards, the couple started to visit the hometown every summer, sometimes staying for a few months at a time with their children. Permanent residency eased the burden of crossing the border and enabled the family to maintain social relationships throughout the town. As a result of their frequent and extensive summer visits in Telepi, Sarita had both bonding and bridging social ties throughout Telepi. For example, her sister was a nun who worked in the region and still lived in Telepi. She also stayed a member of her beloved church group even from afar. Members of the church group were from all corners of Telepi and Sarita got to know many families in pueblos across town through her work in the group. Her active involvement in the local church groups was a key driving force in the development of the new hometown association that she would later form.

During one of their Christmas holiday visits, Sarita got the idea with her church friends to raise small amounts of money and donate it to the church for a new roof. The friends decided to do small fundraisers on both side of the border. Sarita and a few of her immigrant friends in Los Angeles made buttons and tamales to sell at festivals, picnics, and other social events held by Zacatecan immigrant organizations. Residence in the U.S. did not prevent Sarita from staying active in an association she had come to value and where she had made deep connections to other parishioners she left behind when they moved to the U.S.

After the church roof project, Sarita and Leo wanted to continue supporting their town. Since they had stayed in touch with friends and family across Telepi, they kept abreast of the problems in town. Friends of Sarita's who worked in the municipal government frequently complained that they had no vehicle to pick up trash and to use for public works projects in town. Eager to support the provision of a dump truck for the Telepi government, Sarita discussed the idea with the 
other families of Club Social in San Pedro. But while Sarita, Leo, and a few other members wanted to take on bigger public works projects, Martin and the original members of Club Social preferred the club remain more of a social group. With the blessing of the original founders of the club, Sarita, Leo, Fernando, and a few other members left the group and formed a new migrant hometown club, Familias de Telepi. Familias planned to focus exclusively on fundraising collective resources for public goods projects throughout Telepi that would help improve the residents' quality of life.

Since the late 1990s, Familias de Telepi worked to mobilize resources for public goods projects. In the early years of the club, Sarita and the members raised the money, purchased goods, and sent them back to Telepi without support or coordination with the municipal PRI government. But a trip to Telepi during the Christmas holiday in 2001 changed the scale of the club's focus and eagerness to improve social welfare in the hometown even more.

Over the Christmas holiday, Sarita and her church group went caroling in a pueblo outside the county seat. They made food and brought plates to all the poor households. House after house, Sarita and members of the church group found people living in squalor. Elderly grandparents of migrants living in the U.S. had stopped receiving remittances and had very little to eat. In one ranchito, they were invited into the home of an elderly woman whose eyesight had deteriorated so much she could not see the bugs and cockroaches embedded in the tortillas she was making for the carolers. In another home, they met an elderly man who joked he had to "fight the rats for his food." Sarita and her friends were devastated after the visit. When she returned to San Pedro in the new year, she recounted what she saw to the members of the Familias group and they all agreed they must do more for the people of Telepi whose migrant families in the U.S. had "forgotten" their relatives after living abroad for so long. Familias and the church group decided to work on an ambitious project together in the months after the caroling visit to the ranchitos of Telepi. They set out to build a nursing home (asilo de ancianos) for the poor, elderly residents of Telepi.

Even though Sarita was a migrant herself, she shared many of the criticisms nonmigrant residents had about the ways in which migration changed local social life. Residents bemoaned the consumerism that remittances supported and looked down on migrants' displays of wealth (designer handbags), habits (cursing), and dress (tattoos and piercings) that some residents thought migrants flaunted when they returned in December for prolonged visits. There was a great deal of pride in the rural Telepi lifestyle, and some residents were concerned Telepi boys and girls would be lured to the U.S. by materialism instead of finishing high school in town. When I asked about how migration had changed life in Telepi to a group of women in a knitting circle one afternoon, they said American culture eroded Catholic values, neighborliness, and made migrants look down on more traditional customs and practices such as charreada (equestrian competitions similar to an American 
rodeo) and patron saint festivities. Many local residents understood migration to the U.S. as necessary for families' economic well-being, but also associated the migratory process with the introduction of "modern" values and disrespect for rural, traditional modes of cultural life.

Women in the knitting circle acknowledged the tension between migration and cultural values head-on. Martina, a nonmigrant resident, said, "Listen, I understand why people leave. It is a necessarily evil. And paisanos work really hard. My friend's husband has been there [U.S.] for 10 years and he never sees his kids. It is really hard for her. But now it is like they go just for the money and the trucks, and they come back to say how much better it is there. It is not for me." Many of the women nodded their heads when Martina spoke, including Sarita. The selection of the nursing home project was reflective of this concern about migration changing social values in Telepi. Church group members thought the elderly residents who had been cared for by remittances had been "forgotten" by their families. The women identified this issue as one in which they could make a real difference. Sarita shared this view and the nursing home project became the core mission of the group. Sarita and Leo's maintenance of both bonding and bridging ties to residents throughout Telepi and their shared concerns about the disruptive nature migration had on traditional values in the hometown created a common connection and solidarity between the active residents of Telepi and Sarita, the visible ambassador of the migrant club in the hometown.

\section{EXPANSION OF SOCIAL NETWORK TIES DURING THE NURSING HOME PROJECT}

Sarita was embedded in the social base of Telepi and her concern for the people of Telepi was equally matched by her commitment to the migrant club. Sarita said, "This is not like a hobby or something to me. I take this very seriously. We take this very seriously. I will work for this club and for the people of Telepi until I am dead."9 The breadth and depth of both bonding and bridging ties meant that local residents were highly involved in coproduction activities from the very start. Her embeddedness in Telepi after migration meant that the projects the club pursued in Telepi were framed as contributions by and for Telepitenses.

Sarita's social embeddedness was apparent after spending a few weeks in Telepi. It seemed like everyone knew her even though she lived most of the year in the U.S. When she was in town and we walked around town to different project sites, people constantly stopped to say hello or waved to her from across the street. During a bus trip to an outdoor Catholic mass for residents of several nearby municipalities, people rushed to sit next to her and ask after her family. On several occasions, I visited her house to chat and have lunch. During these visits, she either had company already or a neighbor, friend, teacher, or relative knocked on the door for a visit. Because Sarita was still perceived as a member of the community, 
the coproduction of public goods projects her club spearheaded was perceived by most residents as a cross-border extension of social solidarity and community. The strong base of support in the hometown also allowed migrant club members and local partners to more easily recruit residents to take on more active, leadership roles in the coproduction process with the municipal government as the number and scale of projects escalated over time.

Sarita and Leo used both their bridging ties to members of the church group and bonding ties to relatives who remained behind in Telepi as active partners in club activities. Members of the church group included her sister, Elena, the museum director, staff in the ayuntamiento, an owner of a popular fresh juice stall, neighbors on her block, and parents and teachers of the local technical high school. Additionally, Leo recruited his friends from high school who worked in the municipal administration and with whom he shared a migratory experience. They then became involved in the nursing home project. As Sarita, Leo, and the other club members fundraised and planned for the nursing home on the U.S. side of the border, the church group in Telepi fundraised in Mexico. The asilo de ancianos was a huge endeavor even with the support of the local Catholic church. Familias needed financing and technical support from the government to see the project through, since a project of this magnitude was beyond the technical capacity and economies of scale of the migrant group. Sarita decided to meet with a friend and former migrant who had returned to Telepi to work as an engineer for the PRI municipal administration. She hoped he would provide advice and perhaps technical support for the nursing home project.

Ignacio ("Nacho") was an engineer and director of social development for the municipal administration at the time he met with his old friends Sarita and Leo to discuss the nursing home in 2003. A former migrant himself with social ties to Sarita and other HTA members in the federation (his brother-in-law later became the Zacatecan Federation president), Nacho was intrigued by the 3X1 matching grants program he had heard about from his brother in the U.S. When Sarita discussed the nursing home with Nacho and recommended proposing the project through the new federal version of the 3x1 Program, he jumped at the opportunity to be involved. Nacho organized a meeting with the mayor, Sarita, Leo, and members of the church group to formally propose the nursing home project for the municipal partnership. The PRI mayor supported the idea and instructed Nacho to regularly meet with Sarita and travel to Los Angeles when necessary to plan and implement the multi-stage project. A project of this scale would need to be completed over several phases, and Nacho and the director of social development would have to use resources from several different funding streams to make the municipality's 25 percent share. Telepi was a poorer municipality without much capacity to provide more than a few public works projects a year. The 3X1 Program, with cofinancing from the state and federal governments, was viewed by the PRI 
administration as a new resource that could extend their public works budget beyond its limited scope.

While the planning of the nursing home project was underway, Nacho convinced the mayor to work on several additional projects with the migrant club through the 3xi Program. Since Sarita and Leo could not be in town to help with all the planning of the nursing home, they decided, along with members of the church group, to help form a mirror club (club espejo) in Telepi that would work as the Telepi counterpoint to the Familias efforts in Los Angeles. One of the members of the church association, Umberto, was also the director of social communications for the Telepi government and a friend of Leo's from high school. Together with his friends and neighbors, which included a few teachers, store owners, and members of a defunct Rotary club, Umberto recruited everyone to the mirror club that planned to work together with the municipal government and Familias to implement phase one of the nursing home projects. Out of the church association, a new civic association was created to work directly with the migrant club to fundraise materials for the nursing home resident's bedrooms. As more people became involved in the project, they spun out new, smaller committees to work on particular aspects of the project that were meaningful to them.

Sarita's bonding and bridging social ties in Telepi helped to expand the number of residents involved in the coproduction process, and Umberto's connection to Sarita through the church group extended the social network of the migrants in Telepi when he recruited other active residents into the coproduction partnership through his bonding social network of close friends and family. Migrant social embeddedness in Telepi led to high levels of community inclusion in coproduction activities. As a result of their active involvement in coproduction, more residents developed skills and interest in forming their own groups to work on the nursing home project and some projects of their own. For example, the Rotary club, after they raised money for nursing home materials, decided to organize a baseball league for residents to play against other nearby towns. They used the fundraising skills they learned in the migrant club to collect resources for the baseball club's uniforms. High levels of citizen inclusion were characteristic of the transnational coproduction partnership early on and produced positive spillover effects on other forms of civic engagement in Telepi as the partnership took on more 3X1 projects with the municipal government.

\section{A FRIEND AND FORMER MIGRANT BECOMES MAYOR}

In the first phase of the nursing home project, the PRI controlled the state governorship in Zacatecas. Every year, the PRI state transferred revenues to municipalities across the state. Municipalities relied on federal and state revenue transfers to supply public works in their jurisdictions. But as Nacho came to discover, a change 
in the governing party of the state sometimes upset the reliability of municipal funding sources. Nacho recalled, "The [municipal] government did not have much trouble getting funds back then to do a couple projects with the migrant club, but things changed when the PRD took the state from the PRI. It got a lot harder to get money at the local level after that ... With the state and federal 3X1 Program we saw a way to get more money for projects than relying on Ramo 20 alone [revenue-sharing funds called fund 3 and fund 4]." allowed poorer municipalities including Telepi to overcome fiscal constraints to supply public goods through the amplification of public resources from the state and federal governments.

Relying on his experience as social development director, Nacho ran as the PRI candidate for mayor in the municipal election and won. He campaigned on the success of the infrastructure projects he completed with the migrant hometown club and promised to continue public goods provision throughout Telepi when elected. Even though the distribution of revenue transfers became more precarious during his mayorship, Nacho used coproduction and the 3X1 Program to liberate additional resources for municipal development during his tenure as mayor of Telepi from 2006 to 2009.

Nacho's relationship with the migrant leadership of the HTA was an important component of coproduction success during his six-year service in municipal government, first as director of social development and later as mayor. While he sought to prioritize water and electricity projects and job creation in accordance with his development plan, the HTA and local citizens had their own ideas for public projects. The migrant club, local citizen committees, and local government negotiated the selection of projects and worked in tandem at every stage from project design to hiring contractors to monitoring quality standards during implementation. While there were frequent disagreements about which projects to fund as citizens and public officials had different spending priorities, the municipal government, residents, and migrants learned to deliberate. Residents like Lula explained, "Listen, we don't always get the government to agree to all the projects we want, but they seem to try and work with us; like if they say no for a certain project this year, then maybe next year we can do it." The process of coproducing public goods created a new participatory space in which public officials and citizens negotiated project selection and planning, even when it sometimes meant citizens did not get their preferred projects funded the first time.

Nacho designed his entire budget around the 3x1 Program, leading to 30 projects over the course of the two administrations he served. ${ }^{11}$ Public works expenditures (per capita) between 2000 and 2003 averaged $\$ 416$ pesos compared to $\$ 1,082$ in the following electoral cycle. By the end of Nacho's term as mayor, total public works expenditures (per capita) increased to $\$ 1,500$ on average. Coproduction in Telepi increased public expenditures for public goods and services for local residents, improving government responsiveness to social spending in a poor 
municipality, but in which the mayor and his staff had an "entrepreneurial spirit," as one resident described them.

While Familias had special projects they promoted and pursued (the nursing home) through the $3 \times 1$ Program in Telepi, they learned in informal conversations with citizens of Telepi that people had project ideas of their own. Familias began to invite citizens - friends, family, and strangers alike-to initiate project proposals to be funded through the $3 \times 1$ Program while they worked on different phases of the nursing home. When a few residents were excited about a project, they were encouraged to form coordinating "citizen committees." Each project committee oversaw planning and project implementation in concert with municipal staff. Residents wanted ownership over their proposed projects, which was supported by the migrant club and the mayor. Over Nacho's three-year term as mayor, 10 citizen committees proposed, fundraised, and supported projects by monitoring hired contractors and making sure materials arrived on time. The invitation and recruitment of interested citizens into the coproduction process led to the creation of new civil society groups in Telepi. In response to the inclusion of the local citizenry, transnational coproduction helped activate new interest in local politics and more engagement.

Local residents appreciated the increase in civic engagement emanating from the coproduction process in addition to the projects themselves. Eduardo, the director of the technical high school, told me:

The paisano club is kind of like an institution here... We had some of this kind of infrastructure before, but it didn't reach all of the communities and it was very old and needed to be redone ... the club helps makes things happen here. We make a list of priorities and meet with the club and the mayor and we focus together on the most important ones. That is how we got the two new buses for the schoolchildren ... we all donate some money and the parents help to collect donations from their neighbors too. It makes us feel like a real community.

The increase in civic engagement in Telepi had additional spillover effects in the municipality. Citizen committees inspired residents to form neighborhood sports clubs and a Lions Club. In addition to the Lions Club primary activities, they also fundraised and donated washers and dryers for the second stage of the nursing home project. Coproduction based on both citizen inclusion and government engagement had ripple effects. Synergetic coproduction created and scaled up citizen participation in local politics, but it also had important statesociety effects. Locals who participated in citizen committees met regularly with officials in the local government and said they felt more comfortable interacting with local officials than they did before, even when they disagreed. These citizen committees would prove to have additional import in the community when the PRD, an opposition party, narrowly defeated the PRI in the contentious 2007 election. 


\section{DECLINE OF GOVERNMENT ENGAGEMENT DURING POLITICAL PARTY TRANSITION}

The PRD won the 2009 election in a close race and many residents alleged corruption. While Sarita thought of herself as a Priista, she and other club members refused to allow partisan politics to influence club business and their transnational partnership with the municipal government. As soon as Mario, the new PRD mayor, took office, Sarita and the leaders of the three new migrant clubs from Telepi (including Club Social) invited the mayor to a breakfast. At the event, the migrant club leaders hoped to discuss new coproduction projects for collaboration through the 3x1 Program. Sarita recalled that the new mayor was not receptive to their ideas. At the close of the meeting Efrain, another club leader, said they were "skeptical of this new administration" and said Mario was "dismissive" of their past accomplishments. Moreover, Sarita did not think Mario had the requisite professionalization to be an effective leader and coproduction partner. She explained, "He just wanted us to pay for the projects that he wanted. He doesn't even know what the people of Telepi want or need. I don't even think he graduated high school." Familias was not interested in funding projects dictated by the new municipal administration.

The migrants felt slighted that they were not being taken seriously after coproducing more than 30 projects in six years, more than any municipal administration had done in their tenure in Telepi. When migrants and residents began to meet after the meeting with the mayor to discuss future projects, residents were worried that citizens of Telepi would not stay active in town affairs.

The PRD government's dismissal of the projects that the migrant club suggested and the lack of recognition of the club and citizen committees' contributions to public goods provision in Telepi was not well received either by paisanos in the U.S. or residents in Telepi. Ricardo, the museum director, who had voted for the PRD mayor because he did not like the PRI candidate, said he "did not believe [anything] this mayor said." When the mayor began to pave over the cobblestone streets in the main part of town, residents used their network of social ties created during the synergetic period and mobilized against the administration's actions. Umberto explained: "All the projects the mayor wanted to do were pavement projects because they get concrete for free from the state through Coprovi (Consejo Promotor de la Vivienda Popular). All they have to do is pay for some labor and additional supplies. We thought the pavement projects were ruining the provincial feel of our town, so we made him stop."

Local residents circulated a petition in each of their citizen committees and took it door to door to households in their neighborhoods. A member of a citizen committee also wrote an open letter in the paper demanding that the mayor stop the pavement projects. The swift mobilization of local residents in opposition to the mayor's policy through the citizen committees was effective. The municipality 
suspended the concrete pavement projects in response to the political activism of local residents and civil society groups in Telepi. The trust and social network ties to a broad swath of citizens throughout Telepi generated through the synergetic transnational partnership forced the municipal government to change policy course in real time. Residents achieved a measure of social accountability by mobilizing collectively to censure the mayor's actions while in office.

While the residents put a stop to the mayor's unfavorable pavement project, the electoral transition to a new mayor and political party upset the synergetic coproduction partnerships between Familias and the other two main migrant clubs that worked with Nacho's administration. The PRD mayor declined to participate in the 3X1 Program and did not work with any migrant clubs during his tenure as mayor. However, like the Panista mayor in El Cerrito, he tried to claim credit for many of the migrant clubs' projects during the electoral campaign. In my discussion with the mayor, he told me about ten $3 \mathrm{x} 1$ projects he completed during his tenure, although I understood from my conversations with many residents of Telepi and $3 \mathrm{X} 1$ records that these projects were initiated and funded by Nacho's administration and were simply completed after Nacho left office by the PRD regime. During the substitutive period of the PRD administration, the HTAs continued to join forces with citizen groups. They worked together to purchase new drainage pipes that connected a locality to the public system and bought materials to refurbish parts of the local dam. With support from citizen committees created during the synergetic period, the migrants and local citizens completed two projects without municipal government. The only complementary input the municipality provided was right-of-way access to public land to complete the infrastructure projects. This period of low government engagement brought about by the municipal electoral transition halted participatory engagement between citizens and the state but did not affect Telepi residents' interest and desire to continue being civically engaged in local projects with migrant club partners.

\section{POSITIVE SPILLOVER EFFECTS OF SYNERGY AND SUBSTITUTION IN TELEPI}

The case of Telepi demonstrates how synergetic coproduction characterized by strong government and local citizen engagement creates new opportunities for state and nonstate actors to solve local problems through participatory action. Since Sarita had maintained membership in the social life of Telepi, she drew on the resources of her social network to recruit community residents as cooperative coproduction partners. Community participation permitted the exchange of ideas directly between citizens and local government officials and helped citizens gain ownership over the coproduction process. The contributions of the migrant club and citizen committees and the healthy engagement of local representatives led to 
the completion of 30 projects in six years, a marked increase in municipal public works expenditures, and the creation of new civic associations.

When an unengaged municipal administration assumed the mayorship, the organizational partnership form changed. The decline in government engagement, alongside high community inclusion, led to substitution in which migrant clubs in concert with local citizen groups provided public goods independent of the local government. During this period, the local government worked exclusively on pavement projects, but attempted to take credit for coproduction projects without contributing resources, providing public resources, or technical support.

Although the local government was uninvolved in public works provision with migrant and local civil society partners, the increase in civic engagement facilitated by the synergetic partnership had politically efficacious spillover effects in Telepi. When the mayor pursued an unpopular public project, citizen groups mobilized opposition through the social network ties that they had crafted with people around Telepi who worked on public projects with migrants and the PRI local regime. The skills that residents had developed by working together on projects was repurposed to pressure the municipal administration to end the pavement plans throughout town. Even through a period of substitution, citizens identified nonelectoral strategies to levy social control on an unpopular mayor who was dismissive of participatory governance. Locals also used the formal political process to hold the unpopular mayor and his party to account. After learning about the decision-making style of the mayor and lack of support for community civic engagement in public goods affairs, residents reelected the PRI back into the mayorship in the subsequent election. Voters casted ballots in record numbers in 2010, with over 98 percent of the voting-age population turning out to the polls. The PRI resumed the municipal presidency and the PRD experienced an 18 percent decline in vote share in Telepi.

With the ousting of the PRD administration, the synergetic partnership between Familias, citizen groups, and the municipal government resumed. The new PRI administration invited migrants and local leaders to a series of meetings even before they officially took office and sought project proposals from interested actors. Familias continued to engage with residents and the municipal government in coproduction projects through the 3X1 Program. In 2010, the third phase of the nursing home project was completed and became home to 30 elderly Telepi residents.

\section{SUMMARY}

When migrants are embedded in the social base of the hometown community or when they forge social ties to community stakeholders beyond their immediate social circles, citizen inclusion is higher and ordinary citizens are more included in the coproduction process. When government engagement is also high, migrant 
HTAs' complementary remittances link them and residents directly to government representatives responsible for supplying public goods.

Attaining the "best" match of citizen inclusion and government engagement can be difficult to achieve. The case of Telepi shows how government engagement can wane, which upsets synergy and leads to more substitutive partnerships. Municipal electoral transitions between political parties may disrupt coproduction partnerships. The decline or absence of government engagement requires migrant groups and local civil society, if they are involved, to compensate for the lack of official participation. Paisanos and their partners in civil society either work together with state and federal cofinancing partners, or complete public works projects independent of the Mexican state altogether by selecting, coordinating labor and materials, and overseeing the implementation of public works.

But substitutive coproduction may still have some benefits for local democracy. We see in Telepi how citizen inclusion can become politically efficacious for democratic quality outside of the coproduction project arena. Citizen groups drew on social connections to mobilize in response to unpopular municipal decisions and exert more pressure and social control over elected officials they perceived to be behaving badly. Citizens were able to draw on social resources generated in coproduction-social ties, connections, trust, information-to hold public officials accountable for their decisions while in office. Synergy created through coproduction allowed social groups to induce a measure of popular control over local government outside the formal electoral process of electing political parties into power.

In the case of Telepi and El Cerrito, low government engagement led to periods in which the migrant club completed public works projects with very little support from the municipal administration. But as new municipal administrations transitioned in and out of office and different political parties identified electoral incentives to participate more fully, the level of government engagement changed. In El Cerrito, municipal officials ramped up engagement in coproduction as citizens became more involved in the process. As citizens worked directly with paisanos, they were more aware of political officials' performance while in office and had more complete information about public goods funding and provision. Not wanting to be outdone by the migrant HTA in El Cerrito, political officials increased their participation in the coproduction process, allowing them to interface more directly with citizens and claim credit for public goods provision through coproduction in the highly competitive municipality.

When both organizing factors of coproduction are high, more synergy often leads to improved citizen-state relations, more responsive local government, and greater civic and political engagement in migrant hometowns. When migrant social bases provide the HTA heterogeneous links in local society, residents and local government become embedded in a cooperative decision-making apparatus for public goods provision, capturing more of a plurality of societal interests. 
The social ties that bind the state and society provide institutionalized channels for the negotiation and renegotiation of goals and policies. ${ }^{12}$ This nonelectoral mode of political participation expands the institutional terrain in which citizens, migrants, and public officials communicate, negotiate, plan, budget, and implement public works projects that solve local problems through deliberative democratic mechanisms. And in some cases, as El Cerrito and Telepi demonstrate, it also increases voters' interest and willingness to participate in the formal electoral process to reward representatives for performing well while in office and punish others who are less responsive. 